\title{
The effect of an exogenous amylase on performance and total-tract digestibility in lactating dairy cows fed a high-byproduct diet
}

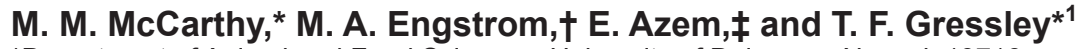 \\ *Department of Animal and Food Sciences, University of Delaware, Newark 19716 \\ †DSM Nutritional Products Inc., Parsippany, NJ 07054 \\ fDSM Nutritional Products Ltd., 4002 Basel, Switzerland
}

\section{ABSTRACT}

The objective of this experiment was to determine the performance and digestibility response of lactating dairy cows fed a reduced-starch diet containing a commercial amylase product. Treatments consisted of a normal-starch total mixed ration (NS-), a reducedstarch total mixed ration (RS-), and a reduced-starch total mixed ration with exogenous amylase (RS+) added to the concentrate. Treatments were assigned according to a replicated $3 \times 3$ Latin square design with 28-d periods. Twenty-three cows completed the study. Starch concentrations in NS-, RS-, and RS+ total mixed rations were $27.7,23.5$, and $22.7 \%$, respectively. Effects of treatment on intake, milk production, milk composition, and total-tract apparent nutrient digestibility were evaluated during the last week of each period. Effects of amylase on in vitro starch digestibility of the NS- and RS- grain mixes were also measured. We hypothesized that the reduction in dietary starch in the RS - ration would decrease diet digestibility and limit milk production compared with NS- due to a decrease in available energy, and that RS+ would alleviate some of this decrease by increasing nutrient digestibility. Contrary to this hypothesis, the RS - diet did not affect intake or milk production relative to the NS- diet, except for increased milk urea nitrogen and a tendency for a decrease in milk protein yield. This lack of response is attributed to both low milk fat concentrations across treatments and greater than predicted dietary energy content preventing the energy deficit that was intended to occur with the reduced-starch rations. Cows fed the RS+ ration had the lowest production performance, with reduced milk, fat-corrected milk, protein, and lactose yields relative to cows fed NS-. Cows fed RS+ also had reduced lactose yield and tended to have reduced milk and fat-corrected milk relative to cows fed $\mathrm{RS}-$. Despite the negative effects of

Received August 8, 2012.

Accepted January 19, 2013.

${ }^{1}$ Corresponding author: gressley@udel.edu the RS+ treatment on performance, exogenous amylase did increase both in vitro and in vivo measurements of digestibility. Although amylase increased nutrient digestibility, this did not translate into improved milk performance, likely due to the relatively high energy content of experimental diets compared with cow requirements.

Key words: amylase, byproduct feeds, starch

\section{INTRODUCTION}

In recent years increased variability in corn prices has increased interest in reducing dietary starch content in lactating rations. Partially replacing corn grain in the ration with high fiber, low starch byproduct feed may be one option to decrease feed costs. However, substituting corn grain with byproduct feed will reduce dietary starch, which can result in less available energy for the cow as well as reduced milk yields (NRC, 2001; Oba and Allen, 2003; Weiss et al., 2011). Byproduct feeds also vary widely in their nutritional content, so strategies to increase carbohydrate digestibility and energy available from byproduct feed will increase their feeding value as a substitute for corn grain.

The addition of exogenous amylase to the ration is one method of enhancing ruminal digestibility of both starch and nonstarch carbohydrates (Tricarico et al., 2008; DiLorenzo et al., 2010). Although the exact mechanism is not known, the addition of amylase to lactating rations has shown an increase in NDF digestibility in the trials of Gencoglu et al. (2010) and Weiss et al. (2011). As byproduct feeds are high in NDF and digestible NDF, the addition of amylase to a reducedstarch, high-byproduct ration may increase the feeding value by increasing NDF digestibility. Adding exogenous amylase to a normal-starch TMR has been shown to increase milk production in lactating cows (Tricarico et al., 2005; Harrison and Tricarico, 2007; Klingerman et al., 2009). However, the response of dairy cows to exogenous amylase when fed rations with byproduct feed substituted for a portion of the corn grain has been more variable. When corn grain was partially replaced with 
soyhulls, the addition of amylase to the reduced-starch ration increased total-tract DM and NDF digestibility and feed conversion to milk relative to both reducedstarch and normal-starch control rations (Gencoglu et al., 2010). However, no improvement in feed conversion or animal performance was found when amylase was added to a diet where corn grain and soybean meal had been partially replaced with wheat middlings and whole cottonseed (Ferraretto et al., 2011). Citrus pulp is a commonly available byproduct feed in the eastern United States, and may provide some benefit when included in rations with reduced starch. Compared with soyhulls, citrus pulp is higher in pectin, lower in NDF, and has a slightly greater in vitro digestibility (Hall et al., 1997; Miron et al., 2001). Adding exogenous amylase to a high-byproduct ration containing citrus pulp and soyhulls may increase rumen carbohydrate digestibility and energy available to support milk production.

The objectives of this trial were to determine the effect of supplementing a reduced-starch diet with an exogenous amylase product on the intake, milk production, and nutrient digestibility of lactating Holstein cows. We hypothesized that the substitution of citrus pulp and soyhulls for corn grain would limit production performance, and that addition of amylase to the reduced-starch diet would alleviate some of this reduction by increasing carbohydrate digestibility.

\section{MATERIALS AND METHODS}

\section{Animals and Diets}

All animal procedures were approved by the University of Delaware Agricultural Animal Care and Use Committee. Cows were housed in a sand-bedded freestall barn and were fed individually via a Calan gate system (American Calan, Northwood, NH). Eighteen multiparous $[80 \pm 32 \mathrm{DIM}$ (mean $\pm \mathrm{SD}$ ), $52 \pm 18 \mathrm{~kg}$ of milk $/ \mathrm{d}$, and $709 \pm 61 \mathrm{~kg}$ of BW at the start of trial] and 6 primiparous (93 $\pm 18 \mathrm{DIM}, 42 \pm 3 \mathrm{~kg}$ of milk/d, and $556 \pm 30 \mathrm{~kg}$ of BW at the start of trial) Holstein cows were used in a replicated $3 \times 3$ Latin square design experiment with 28 -d periods. After a 2 -wk adjustment period, cows were blocked first by parity (primiparous or multiparous) and second by DIM for assignment to the Latin square replicates. Six replicates contained multiparous cows and 2 replicates contained primiparous cows. One primiparous cow failed to completely train to the Calan gates and was removed from the study during the first period, resulting in an incomplete square of primiparous cows.

Cows were ad libitum fed once daily at approximately $0800 \mathrm{~h}$. Refusals from the previous day were weighed and removed before feeding. Cows were milked twice daily at approximately 0500 and $1630 \mathrm{~h}$ and milk production was recorded automatically via computer. During the last week of each period, milk samples were taken at 2 consecutive afternoon and morning milkings. Samples were analyzed by Dairy One Cooperative Inc. (University Park, PA) for milk fat, protein, lactose, and MUN using a Milkoscan System 4000 (Foss North American, Eden Prairie, MN). Cows were weighed on the last $2 \mathrm{~d}$ of the adjustment period and each experimental period. Average BW at the end of each period and BW change over the course of each period were calculated.

The dietary treatments were (1) a normal-starch TMR without exogenous amylase (NS-), (2) a reduced-starch TMR without exogenous amylase (RS-), and (3) a reduced-starch TMR with exogenous amylase (RS+). Rations were balanced using CPM-Dairy (V3.0.10, Ithaca, NY) and contained 59\% forage and $41 \%$ concentrate (Table 1). The NS- TMR contained $12.81 \%$ corn grain, $2.88 \%$ soyhulls, and $2.85 \%$ citrus pulp. Corn grain was partially replaced with soyhulls and citrus pulp to formulate the RS- and RS+ TMR, which contained $6.06 \%$ corn grain, $6.95 \%$ soyhulls, and $6.92 \%$ citrus pulp. Sucrose $(1.03 \%)$ was added to the NS- TMR to account for the sugars provided by additional citrus pulp in the RS- and RS+ TMR. The $\mathrm{NS}$ - ration was balanced to support $40.8 \mathrm{~kg} / \mathrm{d}$ of milk, $3.8 \%$ milk fat, and $3.1 \%$ milk protein with a predicted DMI of $26.8 \mathrm{~kg} / \mathrm{d}$. Using the same intake and milk composition, the RS- and RS+ rations were predicted to support $38.5 \mathrm{~kg} / \mathrm{d}$ of ME-allowable milk (CPM-Dairy V3.0.10).

The amylase for the $\mathrm{RS}+$ ration was provided in a dry form (pure $\alpha$-amylase activity, Ronozyme RumiStar, DSM Nutritional Products, Basel, Switzerland) and blended into the concentrate grain mix during preparation at the feed mill (Renaissance Nutrition Inc., Roaring Springs, PA). The RS+ treatment was designed to provide 732 Kilo Novo units (KNU) of amylase activity per kilogram of grain mix DM and 300 KNU of amylase activity per kilogram of TMR DM. One Kilo Novo unit is the amount of enzyme that releases in a 2-step $\alpha$-amylase/ $\alpha$-glucosidase reaction, $6 \mu \mathrm{mol}$ of $p$-nitrophenol per min from $1.86 \mathrm{~m} M$ ethylidene-G7-pnitrophenyl-maltoheptaoside at $\mathrm{pH} 7.0$ and $37^{\circ} \mathrm{C}$ (Jung and Vogel, 2008).

Silage and TMR samples were collected 3 times a week and stored at $-20^{\circ} \mathrm{C}$. At the end of each week, frozen samples were thawed and composited. Samples of each concentrate mix and hay were collected once a week. Dry matter of weekly feed samples was determined following drying for $48 \mathrm{~h}$ in a forced-air oven at 
Table 1. Ration composition

\begin{tabular}{|c|c|c|c|}
\hline \multirow[b]{2}{*}{ Ingredient, $\%$} & \multicolumn{3}{|c|}{ Treatment $^{1}$} \\
\hline & $\mathrm{NS}-$ & $\mathrm{RS}-$ & $\mathrm{RS}+$ \\
\hline Corn silage & 43.30 & 43.30 & 43.30 \\
\hline Alfalfa silage & 10.50 & 10.50 & 10.50 \\
\hline Alfalfa hay & 5.20 & 5.20 & 5.20 \\
\hline Corn grain, ground & 12.81 & 6.06 & 5.96 \\
\hline Soybean hulls & 2.88 & 6.95 & 6.94 \\
\hline Citrus pulp & 2.85 & 6.92 & 6.92 \\
\hline Sucrose & 1.03 & 0.00 & 0.00 \\
\hline Protected soybean meal ${ }^{2}$ & 6.94 & 6.94 & 6.94 \\
\hline Canola meal & 3.46 & 3.46 & 3.46 \\
\hline Dried corn distillers grains & 3.46 & 3.46 & 3.46 \\
\hline Soybean meal & 2.92 & 2.57 & 2.57 \\
\hline Blood meal & 0.97 & 0.97 & 0.97 \\
\hline Rumen bypass fat ${ }^{3}$ & 0.75 & 0.75 & 0.75 \\
\hline $\mathrm{NaHCO}_{3}{ }^{\circ}$ & 0.63 & 0.63 & 0.63 \\
\hline $\mathrm{CaCO}_{3}$ & 0.56 & 0.56 & 0.56 \\
\hline $\mathrm{NaCl}$ & 0.43 & 0.43 & 0.43 \\
\hline Trace mineral and vitamin $\operatorname{mix}^{4}$ & 0.33 & 0.33 & 0.33 \\
\hline $\mathrm{CaSO}_{4}$, dihydrate & 0.27 & 0.27 & 0.27 \\
\hline Monensin ${ }^{5}$ & 0.27 & 0.27 & 0.27 \\
\hline Urea & 0.21 & 0.21 & 0.21 \\
\hline $\mathrm{MgO}$ & 0.16 & 0.16 & 0.16 \\
\hline Protected methionine $^{6}$ & 0.06 & 0.06 & 0.06 \\
\hline Amylase $^{7}$ & 0.00 & 0.00 & 0.10 \\
\hline
\end{tabular}

${ }^{1}$ Treatments: $\mathrm{NS}-=$ normal starch TMR without amylase; $\mathrm{RS}-=$ reduced starch TMR without amylase; $\mathrm{RS}+=$ reduced starch TMR with exogenous amylase.

${ }^{2}$ Extruded and expelled soybean meal (J. L. Moyer \& Sons Inc., Turbotville, PA).

${ }^{3}$ Calcium soaps of FA with published FA composition of $\geq 85 \%$ C16:0, 3\% C18:0, and 6\% C18:1 (Bergafat F-100, Berg \& Schmidt, Hamburg, Germany).

${ }^{4}$ Contained $33.0 \% \mathrm{Mg}, 8.0 \% \mathrm{~S}, 4.5 \% \mathrm{~K}, 12,028 \mathrm{mg}$ of $\mathrm{Zn} / \mathrm{kg}, 6,017 \mathrm{mg}$ of $\mathrm{Mn} / \mathrm{kg}, 2,252 \mathrm{mg}$ of Cu$/ \mathrm{kg}, 1,918 \mathrm{mg}$ of Fe/kg, $218 \mathrm{mg}$ of I/kg, $164 \mathrm{mg}$ of Co/kg, $84 \mathrm{mg}$ of Se/kg, 1,411 IU of vitamin A/g, $353 \mathrm{IU}$ of vitamin D/g, and $7 \mathrm{IU}$ of vitamin $\mathrm{E} / \mathrm{g}$.

${ }^{5}$ Rumensin 90 (Elanco, Greenfield, IN).

${ }^{6}$ Smartamine M (Adisseo, Alpharetta, GA).

${ }^{7}$ Ronozyme RumiStar (DSM Nutritional Products Ltd., Basel, Switzerland).

$60^{\circ} \mathrm{C}$, with results used for weekly $\mathrm{DM}$ adjustments of TMR mixing. At the end of each period, nutrient composition of TMR composite samples was analyzed by wet chemistry methods (Cumberland Valley Analytical Services, Hagerstown, MD). Samples were analyzed for CP (method 990.03; AOAC International, 2006), NDF using $\alpha$-amylase and sodium sulfite (Van Soest et al., 1991), ADF (method 973.18; AOAC International, 2006), starch (Hall, 2009), sugar (Dubois et al., 1956), lignin (Goering and Van Soest, 1970), and acid ether extract (method 2003.05; AOAC International, 2006). The $\mathrm{NE}_{\mathrm{L}}$ at $3 \times$ maintenance was calculated from nutrient composition using NRC (2001) equations. Batches of the concentrate mixes were produced 3 times during the experiment, with a new batch used each period. Additional concentrate samples were collected weekly and stored at room temperature until composited by period and analyzed for amylase activity by DSM Nutritional Products Analytical Services Center as described by Jung and Vogel (2008).

\section{In Vivo and In Vitro Digestibility Measurements}

A subset of 4 Latin square replicates (12 multiparous cows) was used for apparent total-tract nutrient digestibility determination. Fecal grab samples were collected from those cows via rectal palpation during the last $2 \mathrm{~d}$ of each period. Samples were collected at 4 time points $(0900 \mathrm{~h}$ on d 1, $2100 \mathrm{~h}$ on d 1, $0300 \mathrm{~h}$ on d 2, and $1500 \mathrm{~h}$ on $\mathrm{d} 2$ ) and stored at $-20^{\circ} \mathrm{C}$ until they were composited into 1 sample per cow per period. Each TMR and each cow's refusals were sampled daily during fecal sample collection. Fecal composites, TMR, and refusal samples were dried for $48 \mathrm{~h}$ in a $60^{\circ} \mathrm{C}$ forced-air oven. Dry matter of refusals samples was used for DMI calculations.

Fecal composite and TMR samples were ground through a 2-mm screen using a Wiley Mill (A. H. Thomas Co., Philadelphia, PA) and analyzed for NDF, $\mathrm{N}$, starch, ash, and indigestible NDF. Neutral detergent fiber was determined using sodium sulfite and $\alpha$-amylase (Van Soest et al., 1991) using the Ankom 
200 Fiber Analyzer (Ankom Technology, Macedon, NY). Nitrogen was determined using an Elementar Vario Max CN Analyzer (Elementar Americas Inc., Mt. Laurel, NJ). Starch was analyzed by wet chemistry (Hall, 2009; Cumberland Valley Analytical Services), and ash content was measured following $5 \mathrm{~h}$ at $600^{\circ} \mathrm{C}$ in a muffle furnace. Indigestible NDF was used as a marker to calculate fecal output and apparent totaltract digestibility (Oba and Allen, 2003). Each sample was run in quadruplicate and the indigestible NDF was determined after $120 \mathrm{~h}$ of in vitro rumen incubation using the Goering and Van Soest (1970) method with modifications. These modifications were weighing the samples into filter bags and incubating them in a Daisy ${ }^{\text {II }}$ incubator (Ankom Technology). Rumen fluid for the indigestible NDF incubation was collected from 2 lactating cows being fed the university lactating herd ration. This ration contained $39.4 \%$ corn silage, $9.1 \%$ alfalfa silage, $6.3 \%$ alfalfa hay, $13.1 \%$ ground corn grain, $6.4 \%$ corn hominy, $6.3 \%$ protected soybean meal, $6.0 \%$ canola meal, $2.9 \%$ citrus pulp, $2.4 \%$ soybean hulls, $1.8 \%$ soybean meal, $1.5 \%$ porcine blood meal, $0.9 \%$ sodium bicarbonate, $0.8 \%$ sucrose, $0.4 \%$ corn gluten meal, $0.4 \%$ palm fat, $0.1 \%$ urea, $0.1 \%$ protected methionine, and $2.1 \%$ of minerals and vitamins (predicted nutrient composition $1.66 \mathrm{Mcal} / \mathrm{kg}$ of $\mathrm{NE}_{\mathrm{L}}, 17.6 \% \mathrm{CP}, 32.2 \% \mathrm{NDF}$, $19.1 \%$ ADF, $23.7 \%$ starch, $4.0 \%$ fat, and $7.1 \%$ ash). After $60 \mathrm{~h}$ of incubation, the original rumen fluid and buffer were replaced with fresh fluid and incubation continued for an additional $60 \mathrm{~h}$.

Effect of exogenous amylase on digestibility of starch in composite samples of NS- and RS- concentrate mixes was also determined in vitro in rumen fluid. In vitro assays were conducted at a commercial laboratory (Cumberland Valley Analytical Services) using their standard procedures (Goering and Van Soest, 1970). Briefly, this entailed incubating a 1.00-g sample, $40 \mathrm{~mL}$ of buffer, and $20 \mathrm{~mL}$ of rumen fluid anaerobically for $7 \mathrm{~h}$ at $40^{\circ} \mathrm{C}$ and analyzing for starch as described by Hall (2009). Exogenous amylase treatments were incorporated by replacing $1 \mathrm{~mL}$ of in vitro buffer with $1 \mathrm{~mL}$ of in vitro buffer containing varying concentrations of liquid amylase (Ronozyme RumiStar, DSM Nutritional Products). Treatments were assigned as an incomplete $2 \times 4 \times 2$ factorial design consisting of 2 substrates (NS- or RS- concentrate mix), 4 amylase levels (0, $380,1,270$, or $3,800 \mathrm{KNU} / \mathrm{kg}$ of substrate $\mathrm{DM}$ ), and 2 amylase incubation lengths (coincubation during the $7 \mathrm{~h}$ in vitro only or preincubation of buffer, amylase, and substrate for $18 \mathrm{~h}$ aerobically at room temperature followed by the addition of rumen fluid and $7 \mathrm{~h}$ of in vitro incubation). The factorial was incomplete because effects of preincubation were assessed only for the 0 and 1,270 KNU of amylase per kilogram of substrate DM treatments. All treatments that were evaluated were run in sextuplicate, with triplicates run on each of 2 consecutive days.

\section{Statistical Analysis}

For the animal experiment, weekly average milk yield and DMI were calculated for the last week of each period. Fat-corrected milk was calculated as $(0.4324 \times$ $\mathrm{kg} / \mathrm{d}$ of milk $)+(0.16216 \times \%$ milk fat $\times \mathrm{kg} / \mathrm{d}$ of milk $)$. Intake, milk production, milk composition, and BW were evaluated using the mixed model procedure of SAS Institute (2006). Fixed effects were treatment, period, parity, square nested within parity, the interactions of treatment $\times$ period, and the interaction of treatment $x$ parity; cow nested within square was included as a random effect. The Kenward-Roger adjustment for denominator degrees of freedom was used. Nutrient digestibility data were analyzed using a similar mixed model, except that parity was not included because the subset of cows used for nutrient digestibility data were all multiparous. Fixed effects were treatment, period, square, and the interaction of treatment and period. Cow nested within square was considered a random effect. A Students' $t$-test was used to determine differences between treatments.

For the in vitro starch digestibility experiment, data were evaluated using 2 different mixed models. The first mixed model was used to evaluate the effect of coincubation of substrate (NS- or RS- concentrate mix) with different concentrations of amylase $(0,380$, 1,270 , or $3,800 \mathrm{KNU} / \mathrm{kg}$ of substrate DM). This model included the fixed effects of substrate, amylase concentration, and the interaction of substrate by amylase concentration. The in vitro experiment was replicated on 2 consecutive days, and day was included as a random effect. Contrast statements were used to test for linear and quadratic effects of increasing amylase concentration within each substrate. Because amylase concentrations were unequally spaced, the IML procedure of SAS was used to generate orthogonal contrast coefficients. The second mixed model was used to evaluate the effect of preincubation of amylase with substrate on starch digestibility. This model included fixed effects of substrate (NS- or RS- concentrate mix), amylase concentration (0 or $1,270 \mathrm{KNU} / \mathrm{kg}$ of TMR DM), and incubation (coincubation or preincubation). All 2- and 3 -way interactions among substrate, amylase concentration, and incubation were additionally included as fixed effects; day was included as a random effect.

\section{RESULTS AND DISCUSSION}

The NS- ration was balanced to contain $17.3 \% \mathrm{CP}$, $31.5 \%$ NDF, 20.0\% ADF, 27.0\% starch, $43.0 \%$ NFC, 
and $4.5 \%$ fat. Both the RS- and RS+ diets were balanced to contain $17.3 \% \mathrm{CP}, 34.5 \% \mathrm{NDF}, 22.5 \% \mathrm{ADF}$, $22.0 \%$ starch, $39.9 \% \mathrm{NFC}$, and $4.4 \%$ fat. Predicted $\mathrm{NE}_{\mathrm{L}}$ $3 \times$ was $1.70 \mathrm{Mcal} / \mathrm{kg}$ in the $\mathrm{NS}-$ ration and $1.63 \mathrm{Mcal} /$ $\mathrm{kg}$ in the $\mathrm{RS}-$ or $\mathrm{RS}+$ rations (NRC, 2001). Analyzed nutrient composition of diets fed revealed lower $\mathrm{CP}$ and NDF and higher starch, NFC, and fat than formulated (Table 2). Calculated $\mathrm{NE}_{\mathrm{L}}$ values were $0.02,0.05$, and $0.04 \mathrm{Mcal} / \mathrm{kg}$ higher than balanced for NS-, RS-, and $\mathrm{RS}+$ rations, respectively, primarily due to the concentration of fat being higher than expected. In addition to energy content of all diets being greater than expected, the magnitude of the difference in both $\mathrm{NE}_{\mathrm{L}}$ and starch between NS- and the reduced starch treatments was less than intended, and both may have impaired our ability to detect treatment differences. The $\mathrm{RS}+$ ration was formulated to provide $300 \mathrm{KNU}$ of amylase activity per kilogram of ration DM. Actual amylase activity measured in the $\mathrm{RS}+$ grain mix averaged 857 $\mathrm{KNU} / \mathrm{kg}$, resulting in predicted TMR amylase activity of $351 \mathrm{KNU} / \mathrm{kg}$. Measured amylase activity was within the manufacturer's permitted analytical range for the product.

Effects of treatment on performance measures are presented in Table 3. The interaction of treatment and parity was not significant for any measure. Treatment did not affect DMI. The lack of difference in DMI between RS - and NS- was unexpected, as previous work has shown an increase in DMI when corn grain was partially replaced by soybean hulls (Gencoglu et al.,
2010), a mixture of soybean hulls and cottonseed hulls (Beckman and Weiss, 2005), or a mixture of wheat middlings and whole cottonseed (Ferraretto et al., 2011). However, the partial replacement of corn grain with citrus pulp has been shown to reduce DMI in other studies (Solomon et al., 2000; Hall et al. 2010). The differences in passage rate (Piwonka et al., 1994) and fiber digestibility (Heldt et al., 1999) among NFC sources may partially explain differences in DMI response when byproducts are substituted for corn grain. We also found that amylase did not affect DMI, as reflected by no difference between $\mathrm{RS}-$ and $\mathrm{RS}+$. This is in agreement with results of Weiss et al. (2011) but contrasts Gencoglu et al. (2010), who found that addition of amylase to a high-byproduct diet reduced DMI when compared with the high-byproduct diet without amylase.

Dietary treatments affected yields of milk and FCM. Cows fed the $\mathrm{RS}+$ ration had lower yields of milk and FCM compared with cows fed the NS- ration $(P=$ 0.002 and 0.01 , respectively) and tended to have lower yields than cows fed the $\mathrm{RS}-$ ration $(P=0.06$ and 0.09 , respectively). We had hypothesized that partially replacing dietary starch with byproduct feed would reduce milk yield in $\mathrm{RS}-$, compared with cows fed NS-, due to the decreased available energy in the ration (Sarwar et al., 1992; NRC, 2001). Contrary to our hypothesis, no difference in milk yield between cows fed the NS- and RS- rations was observed. This lack of difference may have been due to the greater energy concentrations in the analyzed rations compared with

Table 2. Analyzed ration nutrient composition (standard deviation) of experimental rations

\begin{tabular}{|c|c|c|c|}
\hline \multirow[b]{2}{*}{ Item $^{1}$} & \multicolumn{3}{|c|}{ Treatment $^{2}$} \\
\hline & NS- & RS- & RS+ \\
\hline DM, $\%$ of ration & $51.6(1.0)$ & $52.6(0.5)$ & $52.2(0.4)$ \\
\hline \multicolumn{4}{|l|}{ Nutrient, \% DM } \\
\hline $\mathrm{CP}$ & $16.5(0.8)$ & $16.1(0.1)$ & $16.3(0.1)$ \\
\hline NDF & $29.1(1.4)$ & $32.7(1.3)$ & $32.4(1.3)$ \\
\hline $\mathrm{ADF}$ & $19.5(1.0)$ & $22.6(0.7)$ & $22.5(1.0)$ \\
\hline Starch & $27.6(1.2)$ & $23.7(0.6)$ & $22.9(0.4)$ \\
\hline Sugar & $4.7(0.3)$ & $5.0(0.5)$ & $5.5(0.6)$ \\
\hline Lignin & $3.8(0.8)$ & $4.1(0.5)$ & $4.0(0.6)$ \\
\hline NFC & $43.8(1.1)$ & $40.7(1.2)$ & $41.2(1.6)$ \\
\hline Crude fat & $5.5(0.8)$ & $5.5(0.1)$ & $5.1(0.5)$ \\
\hline Unsaturated $\mathrm{FA}^{3}$ & 2.0 & 2.0 & 2.0 \\
\hline Ash & $6.9(0.6)$ & $6.9(0.2)$ & $6.9(0.2)$ \\
\hline $\mathrm{NE}_{\mathrm{L}},{ }^{4} \mathrm{Mcal} / \mathrm{kg}$ & 1.72 & 1.68 & 1.67 \\
\hline Amylase ${ }^{5} \mathrm{KNU} / \mathrm{kg}$ & - & - & $351(100)$ \\
\hline
\end{tabular}

${ }^{1}$ Nutrient composition as analyzed by wet chemistry by Cumberland Valley Analytical Services (Hagerstown, $\mathrm{MD})$, unless otherwise indicated.

${ }^{2}$ Treatments: NS $-=$ normal starch TMR without amylase; RS $-=$ reduced starch TMR without amylase; $\mathrm{RS}+=$ reduced starch TMR with exogenous amylase.

${ }^{3}$ Unsaturated FA = sum of C18:1, C18:2, and C18:3. Determined for a single composite sample for each ration. ${ }^{4}$ Calculated according to NRC (2001).

${ }^{5}$ Amylase activity of RS+ grain mix samples was measured once each period in Kilo Novo units (KNU) following the procedure of Jung and Vogel (2008). 
Table 3. Milk production, composition, and intake

\begin{tabular}{|c|c|c|c|c|c|c|c|}
\hline \multirow[b]{2}{*}{ Item } & \multicolumn{3}{|c|}{ Treatment $^{1}$} & \multirow[b]{2}{*}{ SEM } & \multicolumn{3}{|c|}{$P$-value } \\
\hline & $\mathrm{NS}-$ & $\mathrm{RS}-$ & RS+ & & $\begin{array}{c}\text { NS- vs. } \\
\text { RS- }\end{array}$ & $\begin{array}{c}\text { NS- vs. } \\
\text { RS+ }\end{array}$ & $\begin{array}{c}\text { RS - vs. } \\
\text { RS+ }\end{array}$ \\
\hline \multicolumn{8}{|l|}{ DMI } \\
\hline $\mathrm{kg} / \mathrm{d}$ & 25.3 & 25.3 & 24.7 & 0.7 & 0.94 & 0.28 & 0.32 \\
\hline$\% \mathrm{BW}$ & 3.79 & 3.77 & 3.69 & 0.10 & 0.81 & 0.25 & 0.35 \\
\hline Milk, kg/d & 47.7 & 46.6 & 45.0 & 1.5 & 0.19 & 0.002 & 0.06 \\
\hline $\mathrm{FCM}^{2}, \mathrm{~kg} / \mathrm{d}$ & 42.4 & 41.6 & 40.1 & 1.3 & 0.33 & 0.01 & 0.09 \\
\hline Milk/DMI & 1.89 & 1.86 & 1.83 & 0.05 & 0.46 & 0.19 & 0.56 \\
\hline \multicolumn{8}{|l|}{ Milk fat } \\
\hline$\%$ & 2.83 & 2.84 & 2.85 & 0.16 & 0.95 & 0.85 & 0.89 \\
\hline $\mathrm{kg} / \mathrm{d}$ & 1.34 & 1.32 & 1.28 & 0.07 & 0.61 & 0.12 & 0.29 \\
\hline \multicolumn{8}{|l|}{ Milk protein } \\
\hline$\%$ & 2.96 & 2.92 & 2.98 & 0.04 & 0.05 & 0.39 & 0.006 \\
\hline $\mathrm{kg} / \mathrm{d}$ & 1.40 & 1.35 & 1.33 & 0.04 & 0.06 & 0.01 & 0.45 \\
\hline \multicolumn{8}{|l|}{ Milk lactose } \\
\hline$\%$ & 4.78 & 4.76 & 4.73 & 0.04 & 0.59 & 0.08 & 0.21 \\
\hline $\mathrm{kg} / \mathrm{d}$ & 2.27 & 2.21 & 2.12 & 0.07 & 0.17 & 0.001 & 0.03 \\
\hline MUN, mg/dL & 10.44 & 11.34 & 10.80 & 0.50 & 0.01 & 0.10 & 0.33 \\
\hline $\mathrm{BW}, \mathrm{kg}$ & 670 & 670 & 669 & 18 & 0.90 & 0.96 & 0.87 \\
\hline BW change, kg/d & 0.44 & 0.60 & 0.79 & 0.23 & 0.60 & 0.26 & 0.55 \\
\hline
\end{tabular}

${ }^{1}$ Treatments: NS $-=$ normal starch TMR without amylase; RS $-=$ reduced starch TMR without amylase; $\mathrm{RS}+=$ reduced starch TMR with exogenous amylase.

${ }^{2} 3.5 \%$ FCM, calculated as $0.4324 \times$ milk $(\mathrm{kg} / \mathrm{d})+16.216 \times$ fat $(\mathrm{kg} / \mathrm{d}) / 100 \times$ milk $(\mathrm{kg} / \mathrm{d})$.

formulated rations, particularly for the reduced starch rations. Ferraretto et al. (2011) and Beckman and Weiss (2005) found no difference in milk yield when corn was partially replaced with either wheat middlings and whole cottonseed or soyhulls and cottonseed hulls, respectively. We had also expected the addition of amylase to the reduced starch ration to increase milk yield, however, cows on the RS+ diet tended to produce 1.6 and $1.5 \mathrm{~kg} / \mathrm{d}$ less milk and FCM, respectively, than cows on the RS- diet. Incorporation of amylase into normal starch rations has been shown to increase milk production (DeFrain et al. 2005; Tricarico et al., 2005; Harrison and Tricarico, 2007; Klingerman et al., 2009); whereas others have found that addition of amylase to reduced starch rations did not affect milk production (Gencoglu et al., 2010; Ferraretto et al., 2011; Weiss et al., 2011).We believe that most of the difference in milk yield in the present experiment was due to the numeric decrease in DMI for RS+ compared with RS-. When the actual DMI and milk components were put through the CPM model for each diet, the predicted ME-allowable milk yields were $45.6,43.8$, and $42.3 \mathrm{~kg} / \mathrm{d}$ for NS-, RS-, and RS+ respectively. The $1.5 \mathrm{~kg} / \mathrm{d}$ predicted difference in milk yield for RS- compared with $\mathrm{RS}+$ was nearly identical to the observed value of $1.6 \mathrm{~kg} / \mathrm{d}$.

Despite the negative production response to exogenous amylase in comparison with NS-, milk yield per unit of DMI was unaffected by treatment; BW and BW change were also unaffected by treatment. We expected
RS - to have decreased feed efficiency compared with $\mathrm{NS}-$, as the RS- diet was intended to contain less $\mathrm{NE}_{\mathrm{L}}$. Others have reported mixed effects from the addition of amylase to reduced-starch diets on feed efficiency. Gencoglu et al. (2010) found that exogenous amylase increased feed efficiency, whereas Ferraretto et al. (2011) and Weiss et al. (2011) found no effect.

During this trial the milk fat was low for all treatments. We suspect that the high unsaturated FA content in these diets altered rumen fermentation and resulted in a ruminal biohydrogenation profile that reduced milk fat synthesis (Bauman et al., 2011). Normal ranges for unsaturated FA intake average 300 to 400 $\mathrm{g} / \mathrm{d}$, whereas intake of greater than $500 \mathrm{~g} / \mathrm{d}$ begins to increase the risk of milk fat depression (Lock, 2009). Unsaturated FA comprised $2.0 \%$ of diet DM for all treatments (Table 2), resulting in predicted unsaturated FA intakes of 527, 521, and $502 \mathrm{~g} / \mathrm{d}$ for the NS-, RS-, and RS+ treatments, respectively. The current diets were heavily based on corn silage, which, along with the inclusion of corn grain, dried corn distillers grains, and monensin, created a highly fermentable diet that exacerbated the opportunity for milk fat depression (A. L. Lock, Michigan State University, East Lansing, MI, personal communication). The low milk fat across diets likely reduced energy requirements and contributed to the lack of differences in milk production between the NS - and RS - treatments.

Both NS- and RS+ cows had increased milk protein percentage $(P=0.05$ and $P=0.006$, respectively) 
compared with RS- cows. Yields of milk protein were lower for RS+ cows and tended to be lower for RScows $(P=0.01$ and $P=0.06$, respectively) compared with NS- cows. The reduction in ration-starch content may have limited rumen microbial protein production and flow leading to a decrease in milk protein yield (Ipharraguerre and Clark, 2003; Oba and Allen, 2003). Relative to cows fed NS-, cows fed RS- and RS+ had, and tended to have higher MUN $(P=0.01$ and $P=$ 0.10 , respectively). Beckman and Weiss (2005), Gencoglu et al. (2010), and Ferraretto et al. (2011) similarly observed increased MUN in cows fed reduced-starch diets compared with those fed a normal starch diet. Weiss et al. (2011) reported no difference among treatments in MUN, although the reduced-starch ration in their trial contained $26 \%$ starch and was likely adequate to support similar levels of microbial protein production in comparison with the $31 \%$ starch control ration. The higher MUN concentration and lower protein yield for cows fed the reduced-starch rations in the current experiment suggest that perhaps less microbial protein was available to support milk protein yield in the reduced starch rations compared with NS- (Oba and Allen, 2003). Cows fed RS+ had decreased lactose yield compared with both NS- and RS - cows $(P=0.001$ and 0.03 , respectively) due to the differences in overall milk yields as well as a tendency for lactose percentage to be lower in $\mathrm{RS}+$ cows compared with NS- cows $(P=0.08)$. Gencoglu et al. (2010) reported no differences in lactose percentage or yield for dietary starch level or enzyme treatment. Ferraretto et al. (2011) and Weiss et al. (2011) found that reduced dietary starch reduced lactose yield. Cows fed reduced-starch diets in both of these previous trials had numerically lower milk yields in both trials, however, the addition of enzyme to the reduced-starch treatment did not further depress lactose yield.

We had hypothesized that the addition of amylase would stimulate ruminal cross feeding, where starch hydrolysis products provide substrate to other nonamylolytic organisms in the rumen (Tricarico et al.,
2008), and increase apparent total-tract digestibility of the RS+ cows compared with RS- cows. In support of this hypothesis, cows fed RS+ had increased DM digestibility $(P=0.03)$ and tended to have increased OM digestibility $(P=0.10)$ compared with RS- (Table 4). No difference in DM or OM digestibility was observed between the NS- diet and either of the RS diets. Gencoglu et al. (2010) similarly observed an increase in DM and OM digestibility for cows fed a reducedstarch diet with exogenous amylase compared with a reduced-starch diet without amylase. In contrast, Weiss et al. (2011) reported no effect of enzyme on DM or OM digestibility, and found that reduced dietary starch resulted in decreased DM and OM digestibility. No differences were noted among treatments for apparent total-tract starch digestibility (average of $99.1 \%$ across treatments). Whereas Weiss et al. (2011) observed much lower starch digestibility (average of $88.5 \%$ ), they also found no effect of amylase on starch digestibility. In contrast, Gencoglu et al. (2010) observed increased starch digestibility in both reduced starch diets with and without amylase when compared with the normal starch control diet.

Cows fed both RS - and RS+ diets had higher NDF digestibility compared with NS- $(P=0.03$ and 0.004 , respectively); increased NDF digestibility in reducedstarch diets has been previously observed (Gencoglu et al., 2010; Weiss et al., 2011). Byproduct feeds have highly digestible NDF (Firkins, 1997), and the increased inclusion of byproduct feed in the RS- and RS+ rations likely contributed to increased NDF digestibility. We did not observe an increase in NDF digestibility for RS+ compared with RS-, a finding in contrast to previous trials that have shown increased NDF digestibility with exogenous amylase (Tricarico et al., 2008; Klingerman et al., 2009; Gencoglu et al., 2010). In the current trial, an increase in $\mathrm{CP}$ digestibility for RS+ compared with $\mathrm{RS}-$ cows $(P=0.05)$ was observed. Gencoglu et al. (2010) similarly observed an increase in CP digestibility with exogenous amylase, but Weiss et al. (2011) reported no effect of amylase on CP digestibil-

Table 4. Apparent total-tract nutrient digestibility

\begin{tabular}{|c|c|c|c|c|c|c|c|}
\hline \multirow[b]{2}{*}{ Item, \% } & \multicolumn{3}{|c|}{ Treatment $^{1}$} & \multirow[b]{2}{*}{ SEM } & \multicolumn{3}{|c|}{$P$-value } \\
\hline & NS- & RS- & RS+ & & $\begin{array}{c}\text { NS- vs. } \\
\text { RS- }\end{array}$ & $\begin{array}{c}\mathrm{NS}-\text { vs. } \\
\mathrm{RS}+\end{array}$ & $\begin{array}{c}\text { RS }- \text { vs. } \\
\text { RS+ }\end{array}$ \\
\hline $\mathrm{DM}$ & 71.1 & 70.1 & 72.1 & 0.6 & 0.27 & 0.24 & 0.03 \\
\hline $\mathrm{OM}$ & 73.2 & 72.0 & 73.4 & 0.6 & 0.18 & 0.84 & 0.12 \\
\hline Starch & 99.0 & 99.2 & 99.1 & 0.1 & 0.09 & 0.31 & 0.42 \\
\hline $\mathrm{NDF}$ & 41.4 & 46.2 & 48.0 & 1.5 & 0.03 & 0.003 & 0.35 \\
\hline $\mathrm{CP}$ & 72.7 & 71.1 & 73.4 & 0.9 & 0.18 & 0.54 & 0.06 \\
\hline
\end{tabular}

${ }^{1}$ Treatments: NS- $=$ normal starch TMR without amylase; RS $-=$ reduced starch TMR without amylase; RS+ = reduced starch TMR with exogenous amylase. 
ity. Nutrient digestibilities, reported in Table 4, tend to be higher than those previously reported. For example, average DM digestibility in this experiment was $71.1 \%$ compared with a mean of $64.9 \%$ (range 61.8 to $69.4 \%$ ) from several studies using lactating cows (Knowlton et al., 2002; Burkholder et al., 2004; Weiss et al., 2011). We believe that fecal output may have been underestimated, and therefore inflated digestibility calculations. However, we expect differences among treatments in nutrient digestibility would remain significant if this bias was removed.

In the lactation trial, amylase inclusion was targeted at $300 \mathrm{KNU} / \mathrm{kg}$ of TMR DM based on previous work utilizing amylase in normal starch rations (Klingerman et al., 2009). Gencoglu et al. (2010) saw a positive response in feed efficiency with amylase in a reduced starch ration, whereas Ferraretto et al. (2011) saw no effect; Weiss et al. (2011) found no effect on production but a positive effect on digestibility. Because of the variability in response to previous studies utilizing amylase in a reduced-starch ration, it is possible that the amylase concentration fed was either too low or too high to elicit a response in a reduced-starch diet. Alternatively, amylase may not have had enough time to bind to and act on rumen substrates before deactivation by rumen microorganisms. Therefore, we conducted the in vitro digestibility experiment to evaluate the effects of different amylase levels and preincubation without rumen fluid on starch digestibility. We hypothesized that the addition of amylase would increase 7 -h in vitro starch digestibility of both NS- and RS- grain mixes, that starch digestibility would increase as amylase activity increased, and that preincubation of samples with amylase would further increase starch digestibility by allowing more time for enzyme action.

In vitro starch digestibility results are shown in Figure 1. When NS- and RS- grain mixes were coincubated with amylase at $0,380,1,270$, or $3,800 \mathrm{KNU} /$ $\mathrm{kg}$ of grain mix, starch digestibility was affected by substrate $(P<0.001)$, amylase $(P=0.03)$, and the interaction of substrate $\times$ amylase $(P=0.008$; Figure 1A). Linear $(P=0.05)$ and quadratic $(P=0.03)$ effects of increasing amylase concentration were also observed. For the NS- grain mix, coincubation with amylase at $3,800 \mathrm{KNU} / \mathrm{kg}$ increased starch digestibility relative to 0 and $380 \mathrm{KNU} / \mathrm{kg}$, with 1,270 KNU/kg being intermediate. For the RS - grain mix, coincubation with amylase at 380 or $1,270 \mathrm{KNU} / \mathrm{kg}$ increased in vitro starch digestibility relative to the $0 \mathrm{KNU} / \mathrm{kg}$ control; however, a further increase to $3,800 \mathrm{KNU} / \mathrm{kg}$ decreased starch digestibility to the level of the $0 \mathrm{KNU} / \mathrm{kg}$ treatment. Klingerman et al. (2009) observed increased in vitro total VFA production at higher enzyme doses for dent and flint corn grain, although no difference in VFA
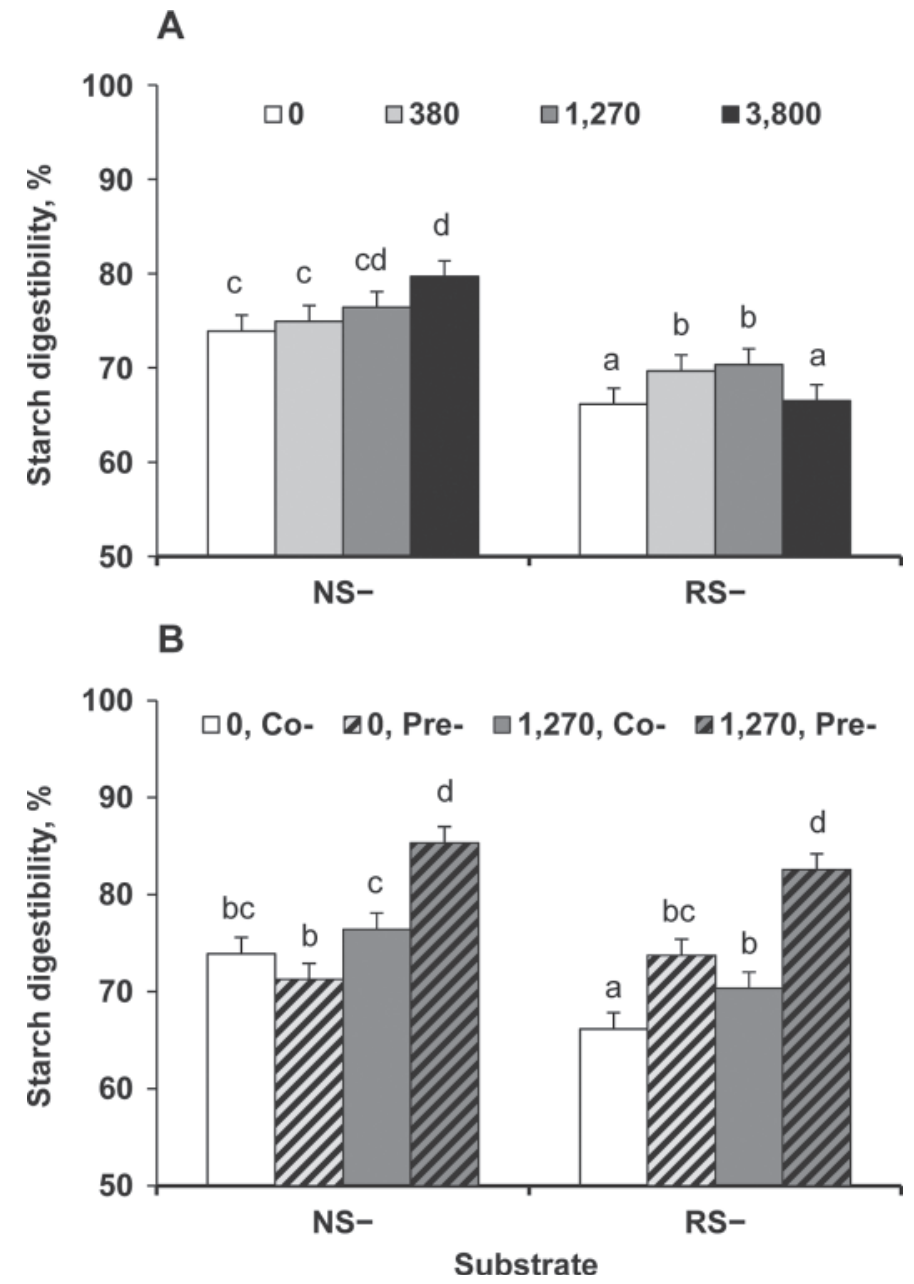

Figure 1. A: In vitro starch digestibility of normal starch (NS-) and reduced starch (RS-) grain mixes incubated in rumen fluid for 7 h with $0,380,1,270$, or 3,800 Kilo Novo units (KNU) of amylase $/ \mathrm{kg}$ substrate DM. B: In vitro starch digestibility of normal starch (NS-) and reduced starch (RS-) grain mixes following $7 \mathrm{~h}$ of in vitro incubation in rumen fluid. Grain mixes were coincubated (Co-) with 0 or $1,270 \mathrm{KNU}$ of amylase $/ \mathrm{kg}$ substrate DM during the $7 \mathrm{~h}$ only or were preincubated (Pre-) with 0 or 1,270 KNU of amylase/kg substrate DM overnight at room temperature under aerobic conditions before the 7-h incubation in rumen fluid. Within each figure means with different letters differ $(P<0.05)$.

production was observed for floury corn grain, which suggests that starch type may affect enzyme efficacy and that starch source and vitreousness may need to be taken into account for determining optimum amylase enzyme inclusion levels in rations.

Because of the importance of adsorption and the binding of enzyme to substrate (Forwood et al., 1990; Beauchemin et al., 2003), we hypothesized that preincubating amylase with substrate would increase in vitro starch digestibility. When NS- and RS- grain mixes were either preincubated or coincubated with amylase at 0 or $1,270 \mathrm{KNU} / \mathrm{kg}$, starch digestibility was affected 
by substrate $(P<0.001)$, amylase $(P<0.001)$, incubation $(P<0.001)$, substrate $\times$ incubation $(P=0.001)$, and amylase $\times$ incubation $(P<0.001)$, and tended to be affected by substrate $x$ amylase $x$ incubation $(P=0.08 ;$ Figure $1 \mathrm{~B})$. For the $0 \mathrm{KNU}$ of amylase $/ \mathrm{kg}$ treatment, no effect of overnight soaking in buffer for the NS- grain mix was noted, but overnight soaking of the RS- grain mix increased in vitro starch digestibility from 66.2 to $73.7 \%(P<0.001)$. However, for the $1,270 \mathrm{KNU} / \mathrm{kg}$ treatment, preincubation increased starch digestibility in both the NS- (from 76.4- 85.3\%; $P<0.001$ ) and RS- (from 70.3-82.6\%; $P<0.001$ ) grain mixes. The effect of preincubation on in vitro starch digestibility was especially beneficial in the RSsubstrate, increasing starch digestibility to similar percentages as observed for the NS- substrate. Enzyme efficacy may be more affected by adsorption and binding time for reduced-starch substrates compared with normal-starch substrates.

\section{CONCLUSIONS}

Feeding a reduced-starch diet formulated by partially replacing corn grain with soyhulls and citrus pulp resulted in increased MUN and NDF digestibility and a tendency for decreased milk protein yield when compared with a normal-starch diet. The addition of exogenous amylase to the reduced-starch diet resulted in decreased milk, FCM, milk protein yield, and milk lactose yield, and increased NDF digestibility compared with the normal-starch diet without amylase. Amylase in the reduced-starch diet increased DM and $\mathrm{CP}$ digestibility compared with the reduced-starch diet without amylase, but did not improve animal production performance.

\section{REFERENCES}

AOAC International. 2006. Official Methods of Analysis. 18th ed. AOAC International, Arlington, VA.

Bauman, D. E., K. J. Harvatine, and A. L. Lock. 2011. Nutrigenomics, rumen-derived bioactive fatty acids, and the regulation of milk fat synthesis. Annu. Rev. Nutr. 31:299-319.

Beauchemin, K. A., D. Collombatto, D. P. Morgavi, and Y. Z. Yang. 2003. Use of exogenous fibrolytic enzymes to improve feed utilization by ruminants. J. Anim. Sci. 81(E. Suppl. 2):E37-E47.

Beckman, J. L., and W. P. Weiss. 2005. Nutrient digestibility of diets with different fiber to starch ratios when fed to lactating dairy cows. J. Dairy Sci. 88:1015-1023.

Burkholder, K. M., A. D. Guyton, J. M. McKinney, and K. F. Knowlton. 2004. The effect of steam flaked or dry ground corn and supplemental phytic acid on nitrogen partitioning in lactating cows and ammonia emission from manure. J. Dairy Sci. 87:2546-2553.

DeFrain, J. M., A. R. Hippen, K. F. Kalscheur, and J. M. Tricarico. 2005. Effects of dietary $\alpha$-amylase on metabolism and performance of transition dairy cows and. J. Dairy Sci. 88:4405-4413.

DiLorenzo, N., D. R. Smith, M. J. Quinn, M. L. May, C. H. Ponce, W. Steinberg, M. A. Engstrom, and M. L. Galyean. 2010. Effects of grain processing and supplementation with exogenous amylase on nutrient digestibility in feedlot diets. Livest. Sci. 137:178-184.

Dubois, M., K. A. Gilles, J. K. Hamilton, P. A. Rebers, and F. Smith. 1956. Colorimetric method for determination of sugars and related substances. Anal. Chem. 28:350-356.

Ferraretto, L. F., R. D. Shaver, M. Espineira, H. Gencoglu, and S. J. Bertics. 2011. Influence of a reduced-starch diet with or without exogenous amylase on lactation performance by dairy cows. J. Dairy Sci. 94:1490-1499.

Firkins, J. L. 1997. Effects of feeding nonforage fiber sources on site of fiber digestion. J. Dairy Sci. 80:1426-1437.

Forwood, J. R., D. A. Sleper, and J. A. Henning. 1990. Topical cellulase application effects on tall fescue digestibility. Agron. J. 82:909-913.

Gencoglu, H., R. D. Shaver, W. Steinberg, J. Ensink, L. F. Ferraretto, S. J. Bertics, J. C. Lopes, and M. S. Akins. 2010. Effect of feeding a reduced-starch diet with or without amylase addition on lactation performance in dairy cows. J. Dairy Sci. 93:723-732.

Goering, H. K., and P. J. Van Soest. 1970. Forage Fiber Analyses (Apparatus, Reagents, Procedures, and Some Applications). Agric. Handbook. No 379. ARS-USDA, Washington, DC.

Hall, M. B. 2009. Analysis of starch, including maltooligosaccharides, in animal feeds: A comparison of methods for AOAC collaborative study. J. AOAC Int. 92:42-49.

Hall, M. B., C. C. Larson, and C. J. Wilcox. 2010. Carbohydrate source and protein degradability alter lactation, ruminal, and blood measures. J. Dairy Sci. 93:311-322.

Hall, M. B., B. A. Lewis, P. J. Van Soest, and L. E. Chase. 1997. A simple method for estimation of neutral detergent-soluble fibre. J. Sci. Food Agric. 74:441-449.

Harrison, G. A., and J. M. Tricarico. 2007. Case study: Effects of an Aspergillus oryzae containing alpha amylase on lactational performance in commercial dairy herds Prof. Anim. Sci. 23:291-294.

Heldt, J. S., R. C. Cochran, G. L. Stokka, C. G. Farmer, C. P. Mathis, E. C. Titgemeyer, and T. G. Nagaraja. 1999. Effects of different supplemental sugars and starch fed in combination with degradable intake protein on low-quality forage use by beef steers. J. Anim. Sci. 77:2793-2802.

Ipharraguerre, I. R., and J. H. Clark. 2003. Soyhulls as an alternative feed for lactating dairy cows: A review. J. Dairy Sci. 86:10521073.

Jung, S., and K. Vogel. 2008. Determination of Ronozyme Rumi-Star Alpha-Amylase Activity in Feed and Per Se Samples. DSM Nutritional Products Ltd. Regulatory Report No. 2500706. DSM Nutritional Products Ltd., Basel, Switzerland.

Klingerman, C. M., W. Hu, E. E. McDonell, M. C. DerBedrosian, and L. Kung Jr. 2009. An evaluation of exogenous enzymes with amylolytic activity for dairy cows. J. Dairy Sci. 92:1050-1059.

Knowlton, K. F., J. M. McKinney, and C. Cobb. 2002. Effect of a direct-fed fibrolytic enzyme formulation on nutrient intake, partitioning, and excretion in early and late lactation Holstein cows. J. Dairy Sci. 85:3328-3335.

Lock, A. L. 2009. Understanding the causes of milk fat depression: From basic concepts to practical application. Proc. California Anim. Nutr. Conf. California State University-Fresno. May 27. California State University, Fresno.

Miron, J., E. Yosef, and D. Ben-Ghedalia. 2001. Composition and in vitro digestibility of monosaccharide constituents of selected byproduct feeds. J. Agric. Food Chem. 49:2322-2326.

NRC (National Research Council). 2001. Nutrient Requirements of Dairy Cattle. 7th rev. ed. Natl. Acad. Sci., Washington, DC.

Oba, M., and M. S. Allen. 2003. Effects of corn grain conservation method on feeding behavior and productivity of lactating dairy cows at two dietary starch concentrations. J. Dairy Sci. 86:174183.

Piwonka, E. J., J. L. Firkins, and B. L. Hull. 1994. Digestion in the rumen and total tract of forage-based diets with starch or dextrose supplements fed to Holstein heifers. J. Dairy Sci. 77:1570-1579.

Sarwar, M., J. L. Firkins, and M. L. Eastridge. 1992. Effects of varying forage or concentrate carbohydrates on nutrient digestibilities and milk production by dairy cows. J. Dairy Sci. 75:1533-1542. 
SAS Institute. 2006. User's Guide: Statistics. Version 9.1.3. SAS Inst. Inc., Cary, NC.

Solomon, R., L. E. Chase, D. Ben-Ghedalia, and D. E. Bauman. 2000. The effect of nonstructural carbohydrate and addition of full fat extruded soybeans on the concentration of conjugated linoleic acid in the milk fat of dairy cows. J. Dairy Sci. 83:1322-1329.

Tricarico, J. M., J. D. Johnston, and K. A. Dawson. 2008. Dietary supplementation of ruminant diets with an Aspergillus oryzae $\alpha$-amylase. Anim. Feed Sci. Technol. 145:136-150.

Tricarico, J. M., J. D. Johnston, K. A. Dawson, K. C. Hanson, K. R. McLeod, and D. L. Harmon. 2005. The effects of an Aspergillus oryzae extract containing alpha-amylase activity on ruminal fermentation and milk production in lactating Holstein cows. Anim. Sci. 81:365.

Van Soest, P. J., J. B. Robertson, and B. A. Lewis. 1991. Methods for dietary fiber, neutral detergent fiber, and nonstarch polysaccharides in relation to animal nutrition. J. Dairy Sci. 74:3583-3597.

Weiss, W. P., W. Steinberg, and M. A. Engstrom. 2011. Milk production and nutrient digestibility by dairy cows when fed exogenous amylase with coarsely ground dry corn. J. Dairy Sci. 94:24922499. 